\title{
Embolic pulmonary complication of a cerebral arteriovenous malformation treatment
}

\author{
Lucas Alverne Freitas de Albuquerque ${ }^{1}$, João Paulo Cavalcante de Almeida² \\ ${ }^{1}$ Intern, Neurosurgery, Santa Casa de Belo Horizonte, Belo Horizonte, MG, Brazil \\ ${ }^{2}$ Intern, Neurosurgery, Universidade Estadual de Campinas (UNICAMP), Campinas, SP, Brazil \\ Study conducted at Hospital Geral de Fortaleza, Fortaleza, CE, Brazil
}

Correspondence to: Lucas Alverne Freitas de Albuquerque - Rua Aimorés, 1006 - apt 202, Funcionários - Belo Horizonte - MG - CEP: $30140-071$ - Brazil lucasalverne@yahoo.com.br

@2011 Elsevier Editora Ltda.Todos os direitos reservados.

A 34-year-old man was admitted in the emergency room with headache, vomiting, gait ataxia, dizziness and vertigo. He was submitted to a cranial CT that showed an important hydrocephalus secondary to a forth ventricle compression by a posterior fossa hematoma. He received advanced life support in an intensive care unit (ICU) and was submitted to an external ventricular drainage (EVD), posteriorly converted to ventriculoperitoneal shunt (VPS) (visualized in the right hemithorax). After stabilization a magnetic resonance image (MRI) and an arteriography revealed a large cerebellum arteriovenous malformation (AVM).

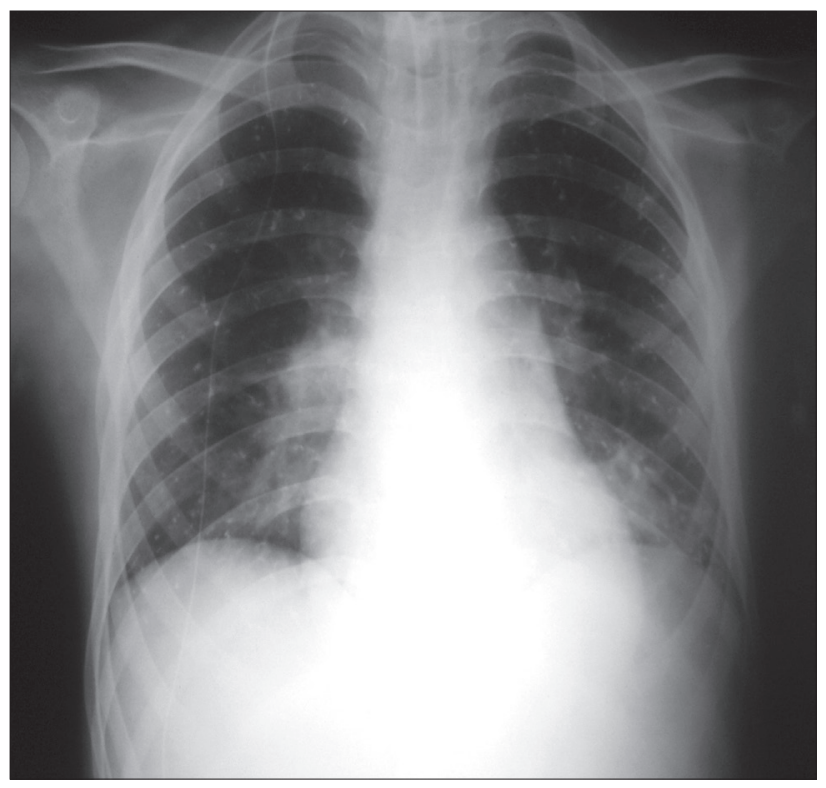

Figure 1 - Lateral x-ray.

\section{RefERENCES}

1. Lv X, Wu Z, Jiang C, Li Y, Yang X, Zhang Y, Zhang N. Complication risk of endovascular embolization for cerebral arteriovenous malformation. Eur J Radiol 2010;Oct 13. [Epub ahead of print]

2. Natarajan SK, Siddiqui AH, Hopkins LN, Boulis NM, Levy EI. To glue or not to glue? That is the question!!! Neurosurgery 2010;67(4):E1181-8.

3. Yuki I, Kim RH, Duckwiler G, Jahan R, Tateshima S, Gonzalez N et al. Treatment of brain arteriovenous malformations with high-flow arteriovenous fistulas: risk and complications associated with endovascular embolization in multimodality treatment. Clinical article. J Neurosurg 2010;113(4):715-22.
It was decided to treat the AVM with surgery preceded by endovascular embolization with N-butyl-cyanoacrylate (Histoacryl). One day after the third section of embolization, the patient evolved to moderate respiratory distress. The x-ray revealed migration of the Histoacryl to the lung. The patient developed respiratory insufficiency and died.

Although nidus embolization with Histoacryl is an effective and safe technique that may permit complete cure of brain AVMs, with or without surgical resection and/ or radiosurgery, serious complications are described ${ }^{1-3}$. There is no specific data related to Histoacryl migration frequency in the endovascular therapy, but it has already been described in the treatment of bleeding gastric ulcer and skull base tumors, as anecdotal cases ${ }^{4-7}$.

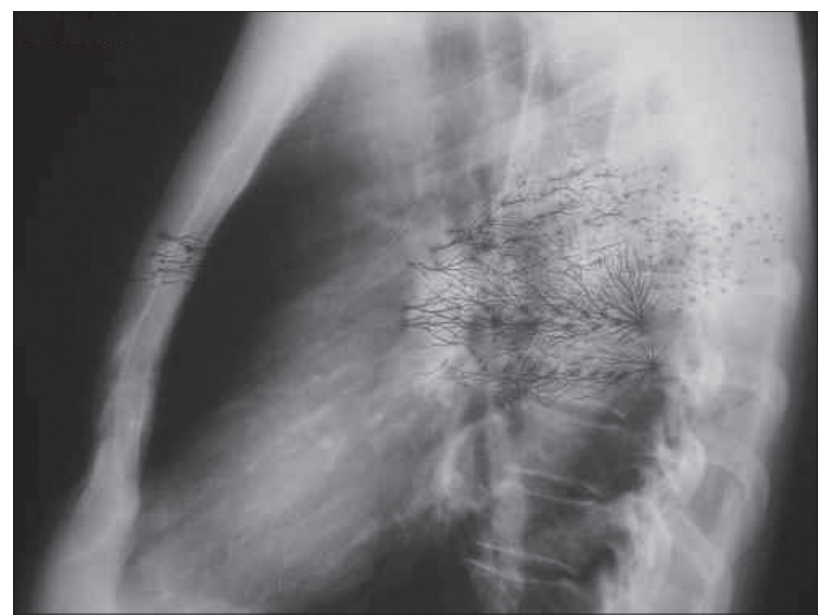

Figure 2 - PA x-ray.

4. Huk W, Becker H. [Complication after embolization of an AVM with Onyx]. Klin Neuroradiol 2009;19(2):145-52.

5. Lee GH, Kim JH, Lee KJ, Yoo BM, Hahm KB, Cho SW et al. Lifethreatening intraabdominal arterial embolization after histoacryl injection for bleeding gastric ulcer. Endoscopy 2000;32(5):422-4.

6. Debrun GM, Aletich V, Ausman JI, Charbel F, Dujovny M. Embolization of the nidus of brain arteriovenous malformations withnbutyl cyanoacrylate. Neurosurgery 1997;40(1):112-21.

7. Casasco A, Houdart E, Biondi A, Jhaveri HS, Herbreteau D, Aymard A et al. Major complications of percutaneous embolization of skullbase tumors. AJNR Am J Neuroradiol 1999;20(1):179-81. 